\title{
Social Development and Security
}

\section{Michael Mulenga Chiti}

The University of Zambia, Lusaka, Zambia

Email: chitimicheal@yahoo.com

How to cite this paper: Chiti, M. M. (2021). Social Development and Security. Open Journal of Business and Management, 9, 2635-2639.

https://doi.org/10.4236/ojbm.2021.95144

Received: June 23, 2021

Accepted: September 27, 2021

Published: September 30, 2021

Copyright (c) 2021 by author(s) and Scientific Research Publishing Inc. This work is licensed under the Creative Commons Attribution International License (CC BY 4.0).

http://creativecommons.org/licenses/by/4.0/

\begin{abstract}
This paper is a study of the Pensions and Insurance Authority (PIA), its regulatory framework, mission, activities and achievement in Zambia. This institution is today a vital pillar to the country's economy and prospects that this presents for the Authority are extensive not only in the development of the industry but also maintaining a robust regulatory framework.
\end{abstract}

\section{Keywords}

Risks, Policyholders, Interdependent, Oligopoly Market, Kinked Demand Curve

\section{Introduction}

The Pensions and Insurance Authority (PIA) is the regulatory and supervisory body for the pensions and insurance industries in Zambia. The Authority falls under the Ministry of Finance and derives its mandate from the Pension Scheme Regulation Act No 28 of 1996 (amended by Act No 27 of 2005) and the insurance Act No 27 of 1997.

The functions of the Authority are monitored by the Board which is appointed by the Minister of Finance in accordance with the provisions of the Act. The Board comprises 9 members that are nominated from various institutions identified in the Amendment Act.

As required under the Pension Scheme Regulation Act, the Board appoints the Registrar, who is the Chief Executive Officer (CEO) of the Authority. The Board also appoints the two Deputy Registrars, the Board Secretary and other members (Chibwe, 2008).

The core functions of the Authority comprise the following:

- Licensing insurance entities (insurance companies, reinsurance companies, reinsurance brokers, brokers, agents and other intermediaries), pension scheme service providers (pension scheme managers, pensions scheme ad- 
ministrators and customers);

- Registration of occupational pension schemes;

- Prudential regulation and supervision of registered and licensed entities;

- Formulation and enforcement of standards of conduct for the pensions and insurance industries;

- Protecting the interests of pension scheme members and insurance policyholders;

- Advising government on matters related to pensions and insurance of national assets and properties.

The strategic plan of the Authority seeks to:

- Establish a stable and sound insurance and pension market;

- Promote and market development;

- Develop and maintain institutional capacity for effective execution of the Authority's mandate;

- Maintain a sound financial position for the Authority (Teachman, 2018).

PIA vision statement: "To be a sound and resilient pensions and insurance industries regulator".

PIA mission statement: "To protect the interests of members and sponsors of occupational pension schemes, insurance policyholders and shareholders and promote the development of the pensions and insurance industries through effective regulation, supervision and excellence in service delivery".

PIA values statements:

- Accountability: we accept the consequences of our decisions and actions;

- Excellence: we endeavour to be diligent, committed, efficient and effective in the execution of our duties;

- Confidentiality: we do not disclose privileged information to any unauthorized persons;

- Integrity: we work with honesty and uphold ethical standards at all times;

- Objectivity: we remain unbiased in the course of our work.

\section{Understanding Insurance Concepts}

Insurance is a contract, represented by a policy, in which an individual or firm, receives monetary protection or refund against losses from an insurance company.

The firm pools clients' risks to make payments more acceptable for the insured.

Insurance is something people purchase to protect themselves from losing money and in exchange of this if something bad happens to the person or thing.

An insurance policy is an agreement between the insurer and the insured. The insurer is the firm that provides the insurance cover. The proposer is the person who takes the cover and is also called the policyholder.

Insurance generates significant impact on the economy by mobilizing domestic savings. Insurance enables to mitigate loss, to achieve financial stability and 
promotes trade and commerce activities that result into economic growth and development. Thus insurance plays a crucial role in sustainable growth of an economy.

Insurance spreads the risk of operations and becomes a means of collecting funds to promote economic growth.

An insurance broker is a person or a firm who purchases and sells insurance products for others or other companies. A broker is an intermediary between clients and producers of services. By acting as an intermediary between the parties, brokers build and maintain customer relationship, execute sales and complete administrative duties, such as document preparation, and follow-up with customers.

\section{PIA Regulation and Supervision}

The Authority continues to remain vigilant and enhances its regulatory and supervisory regime in order to mitigate any risks in the pensions and insurance industry. This is to ensure that the Authority effectively regulates and supervises the pensions and insurance industry. Indeed it the mission of the Authority to have a safe and financially sound industry contributing to the economic development of Zambia.

The Authority further continues to undertake legal reforms. The National Social Bill was under consideration as at 31st December, 2018. The Authority also continues to engage the Ministry of Finance on the proposed insurance bill. The Authority further developed Pension Supervisory modules under the Pensions and Insurance Supervisory Management Information System (PSMIS) and implemented the Fit and Proper Pensions Framework in order to achieve operational efficiency.

\section{PIA Financial Performance}

The Authority had a total approved budget of K50 million. The annual budget was prepared within the framework of the annual work plan derived from the 2019-2021 strategic plan and the 2019 corporate scorecard.

The main sources of revenue for the Authority were levies charged on the pensions and insurance entities pursuant to section 29A of the Pensions Scheme Regulation Act and Statutory Instrument Number 100 of 2007.

The Authority recorded revenue amounting to K57.1 million during the year ended $31^{\text {st }}$ December 2019 (K49.7 million in 2018) representing an increase of 15 percent over the previous year. The increase in revenue is attributed to growth in net assets of pension's funds and increased in insurance Gross Written Premiums. On the other hand, operational costs amounted to K48.5 million (K40.5 million in 2018) accounting for 85 percent of total revenue.

The Authority's total assets increased to K104.7 million in 2019 from K85.5 million in 2018 translating into a 22 percent increase. (Source: data from annual reports 2015, 2016, 2017, 2018, 2019) 


\section{PIA with Stakeholder Engagement}

The Authority held stakeholder consultative workshops with industry in a bid to foster collaboration and development I the pensions and insurance industry.

Arising from the consultations, a plan of action was agreed with the industries. The plan seeks to promote the development of the insurance industry and includes the following: co-insurance, fronting, bancassurance, the need to regulate the insurance profession and address the skills gap, the need for an information exchange platform akin to the credit reference bureau under the banking sector, creation of a large risk register and review of the National Insurance Credit Policy that was issued by the Authority. The introduction of cash and carry was also discussed.

The Authority also supported the Insurers Association of Zambia (IAZ) in hosting the $4^{\text {th }}$ annual insurance conference from $17^{\text {th }}$ to $19^{\text {th }}$ July 2019 . The conference was held under the theme "enhancing the role of insurance for economic growth", and attracted one hundred sixty-two (162) participants of which included twenty-nine (29) international participants.

Further the Authority in partnership with the Zambia Association of Pensions Fund (ZAPF) organized the inaugural Pensions conference from $19^{\text {th }}$ to $20^{\text {th }}$ November 2019. Apart from deliberating on challenges affecting the Zambia Pensions Industry, the conference served as a platform for the Authority to update industry on development in the Authority and planned interventions. One of the resolutions of the conference was that the Authority issues a Practice Note on transmission of benefit statements through electronic means.

\section{Methodology}

- The author collected data from annual reports from 2015 to 2019. After the analysis of data, information was extracted and evaluated. The narrative was done and conclusion prepared.

- Presentation of the study paper follows the available system template.

\section{Conclusion}

- Some of the greatest achievements of the PIA have been the national financial inclusion strategy, the program of consumer education, and media training workshop and the stakeholder engagement.

- In Zambia, the insurance industry forms an oligopoly market where few firms dominate the market. These firms are interdependent in terms of pricing but independent in terms of ownership.

- In this market, there is a non-price competition where competition is done on the basis of other factors such as quality of service provided.

- There are no barriers to entry, no barriers to exit.

- The demand curve is a kinked demand curve where the demand is elastic for higher prices and inelastic for lower prices. 


\section{Conflicts of Interest}

The author declares no conflicts of interest regarding the publication of this paper.

\section{References}

Chibwe, C. (2008). Unlocking the Potential of Zambian Micro, Small and Medium Enterprises Learning from the International Best Practices-The Southeast Asian Enterprises. Learning from the International Best Practices, Academic Research.

Teachman, G., Lveresque, M. C., Keboa, M. T., Danish, B. A., Mastovakis, K., Noronha, C., \& Madonald, M. E. (2018). Group Peer Review: Reflections on a Model for Teaching and Learning Qualitative Inquiry. International Review of Qualitative Review, 11, No. 4. https://doi.org/10.1525/irqr.2018.11.4.452 